Trinity University

Digital Commons@ Trinity

History Faculty Research

History Department

Fall 1992

\title{
Getting the Facts Straight: New Views of Mexico and Its Peoples in Recently Adopted U.S. History Textbooks in Texas
}

Linda K. Salvucci

TrinityUniversity, 1salvucc@trinity.edu

Follow this and additional works at: https://digitalcommons.trinity.edu/hist_faculty

Part of the History Commons

\section{Repository Citation}

Salvucci, L.K. (1992). Getting the facts straight: New views of Mexico and its peoples in recently adopted U.S. history textbooks in Texas. The Public Historian, 14(4), 57-69. doi: 10.2307/3377860

This Article is brought to you for free and open access by the History Department at Digital Commons @ Trinity. It has been accepted for inclusion in History Faculty Research by an authorized administrator of Digital Commons @ Trinity. For more information, please contact jcostanz@trinity.edu. 


\title{
Getting the Facts Straight: New Views of Mexico and Its Peoples in Recently Adopted U.S. History Textbooks in Texas
}

\author{
Linda K. SAlvucci
}

Every SIX YeArs, the Texas State Board of Education holds public hearings as part of the complex process of "adopting" or approving primary and secondary school textbooks for free distribution to over 1,100 public school districts. Publishers vie to capture a share of this extremely large and lucrative market by placing their products in one of usually five approved slots in each subject category. The significance of the textbook approval process extends far beyond the borders of the Lone Star State, since sales of titles successful in Texas often soar nationwide as well. In an interesting coincidence, the commemoration of 1492 has overlapped with the Texas adoptions cycle for eighth- and ninth-grade U.S. history textbooks. Those who follow these proceedings naturally expected the big story to be the extent to which the new U.S. history

Linda K. SAlvuCCI is associate professor of history at Trinity University in San Antonio. She is a member of the Task Force on Mexico in the $\mathrm{K}-12$ Curriculum and submitted testimony in Austin at the 1991 textbook adoptions hearings. She is completing a book manuscript on trade and the origins of American imperialism in Cuba, 1790-1898. The author wishes to acknowledge support from the Faculty Development Committee of Trinity University and to thank the following colleagues for assistance in the preparation of this article: Allan Kownslar, Char Miller, and especially Julio Noboa Polanco, assistant director of the Tomás Rivera Center at Trinity University. Debra Kile and Lee McAnear of the Texas Education Agency cheerfully filled several requests for written materials that pertained to the 1991 adoptions hearings, while three anonymous referees for The Public Historian offered very useful criticisms of an earlier draft of this essay. None of these individuals bears any responsibility for the opinions expressed herein. 
books reflected themes, such as multiculturalism, inspired by the Columbus quincentenary. ${ }^{1}$

In fact, the newly adopted titles do offer dramatically improved treatment of multilateral and minority issues, particularly those pertaining to Mexico, Mexicans, and Mexican Americans. This is a significant development, since these U.S. history books present, more by default than design, the fullest and most widely disseminated images of Mexico and its peoples to American high-school students. However, the greatly enhanced caliber of the new textbooks has failed to receive the popular recognition it deserves, due to the well-publicized flap over "factual errors" in editions examined by the elected members of the Texas State Board of Education late in 1991. This article attempts to analyze the Mexico-related content of the newly approved textbooks for eighth grade (that is, for U.S. history to 1877), specifically in the context of the recent adoptions hearings and their coverage by the media. It suggests that, despite heightened calls in many circles for more inclusive and intelligent U.S. history textbooks, the actual public debate in Texas over quality remains mired in a very limited conception of the nature of historical studies. The quest for absolute factual accuracy (or "gospel truth" as one board member put it) has overshadowed any discussion of the role of perspective and interpretation in understanding the past. ${ }^{2}$ Indeed, the level of popular discourse regarding history education remains astonishingly low.

There is no question that the number of factual errors uncovered by those perennial critics of Texas textbooks, Mel and Norma Gabler, was appalling and unprecedented. ${ }^{3}$ Picked up first by local and state newspapers and television stations, the mistakes were solemnly reported by the national media, from the CBS Evening News to the Wall Street Journal. The latter highlighted some of the more glaring bloopers: that President Truman dropped the bomb on Korea, that Martin Luther King and Rob-

1. The adoptions process is described more fully below, and in Linda K. Salvucci, "Mexico, Mexicans and Mexican Americans in Secondary-School United States History Textbooks," The History Teacher 24 (February 1991), 203-21. The U.S. history textbooks approved in 1991 represent about 15 percent of the $\$ 131$ million in purchases that will be made by the state of Texas for the 1992-1993 school year. Recent general discussions of the relationship between U.S. history textbooks and multicultural concerns include "Whose America?" Time, July 8, 1991, pp. 12-21, and Robert Reinhold, "Class Struggle," The New York Times Magazine, September 29, 1991, pp. $26 \mathrm{ff}$.

2. See "More than 200 errors prompt panel to fail books," Austin-American Statesman, November 8, 1991 for Board member's comment on "gospel truth." Also see "Publishers catch flak for errors," The Houston Post, November 8, 1991, and "Errors delay approval of texts," The Dallas Morning News, November 8, 1991.

3. Texas began the adoptions list for U.S. history titles in 1962, and Mel and Norma Gabler have been involved in testifying for almost that long. They are best known for their persistent criticisms of biology textbooks for including material about evolution. Along with their associate Neal Frey, an ex-professor of history at Christian Heritage College, they brought the initial 231 factual errors to the attention of the board. Over 3,500 additional errors were later discovered by the Gablers, staff members of the T.E.A., and the publishers themselves. Experts and publishers subsequently estimated that between 90 and 99 percent of the errors were typographical. 
ert Kennedy were assassinated during the Nixon presidency, and that Napoleon was victorious at the battle of Waterloo. ${ }^{4}$ Outraged by several similarly embarrassing gaffes as well as the far more predominant misspellings, transpositions, and typographical errors, the elected members of the board lashed out at the publishers, fining them hundreds of thousands of dollars. Yet in January 1992, the board voted 12-2 to adopt all of the submitted titles after all. ${ }^{5}$ The hoopla over the mistakes has died down, but an important point remains unrecognized: in matters involving Mexico, Mexicans, and Mexican Americans, the qualitative differences between the 1986-92 and 1992-98 adoptions titles are striking.

Examination of the ten U.S. history textbooks adopted in 1985 and used in Texas classrooms between 1986 and 1992 found images of Mexico and its peoples that were inconsistent, idiosyncratic, incorrect, and empty. In general, these now-obsolete texts handled the long history of Mexico before the 1820 s relatively well, but coverage of the nineteenth and twentieth centuries proved deficient in several respects. For example, the Texas Rebellion was portrayed in the 1986-1992 books as an "us versus them" contest, with the most egregious anti-Mexican stereotypes used in descriptions of the battle of the Alamo. Regarding the more recent past, Mexican-American experiences were lumped into catch-all treatments of minorities in general or were highlighted for the problems which they posed for mainstream American politics and society. Attempts to discuss

4. Gary Putka, "Readers of Latest U.S. History Textbooks Discover a Storehouse of Misinformation," The Wall Street Journal, February 12, 1992, B1-B2.

5. "Education board adopts textbooks, fines publishers" The Dallas Morning News, January 11, 1992, and "Board approves 5 history textbooks," The Houston Post, January 11, 1992. Some of the titles were still only conditionally adopted at this point, with final approval coming in March after more newly found errors were corrected. The Texas Commissioner of Education, Lionel R. Meno, recommended that the publishers be fined on a sliding scale for the mistakes, in the amount of over $\$ 230,000$, to be delivered in free books to the state.

The four textbooks adopted for use in Texas public schools for 1992-1998 for Grade 8 (U.S. History and Citizenship through Reconstruction) are: James West Davidson and Kathleen Underwood, American Journey: The Quest for Liberty to 1877, Vol. I (Englewood Cliffs, N.J.: Prentice-Hall, 1992); Robert A. Divine, T.H. Breen, et al., America: The People and the Dream: Vol. I, The Early Years (Glenview, Ill.: Scott, Foresman, 1992); John Garraty, The Story of America: Beginnings to 1877 (Austin, Tex.: Holt, Rinehart and Winston, 1992); and Lorna Mason, William Jay Jacobs, and Robert P. Ludlum, The History of the United States: Beginnings to 1877, Vol. I: Texas Edition (Boston, Mass.: Houghton Mifflin, 1992). For Grades 9-12 (U.S. History and Citizenship from Reconstruction to the Present), the following six titles were all eventually adopted: Carol Berkin, Alan Brinkley et al., American Voices: A History of the United States, Vol. II (Glenview, Ill.: Scott, Foresman, 1992); James West Davidson, Mark H. Lytle, and Michael B. Stoff, American Journey: The Quest for Liberty since 1865, Vol. II (Englewood Cliffs, N.J.: Prentice-Hall, 1992); Thomas V. DiBacco, Lorna C. Mason, Christian G. Appy, History of the United States, Vol. II, Texas Edition (Boston, Mass.: Houghton Mifflin, 1992); Robert Divine, T.H. Breen, et al., America: The People and the Dream, Vol. II (Glenview, Ill.: Scott, Foresman, 1992); John Garraty, The Story of America, Vol. II: 1865 to the Present (Austin, Tex.: Holt, Rinehart and Winston, 1992); and Gary B. Nash, American Odyssey: The United States in the Twentieth Century (Columbus, Ohio: Glencoe Division of Macmillan/McGraw-Hill, 1992). The number of submissions by publishers was dramatically reduced from 1985 , when twenty-five titles vied for ten places on the 1986-1992 list. For this article, the author consulted those versions (mostly the annotated teachers' editions) that were available at the T.E.A.'s Regional Service Center 20 in San Antonio. 
Hispanic role models and positive contributions to the larger culture came across as awkward at best. In several instances, it seemed that a silent historical record was preferable to the botched, clumsy, and half-hearted efforts to be inclusive. ${ }^{6}$

At first glance, these deficiences might seem surprising, given the proximity of Texas to the Mexican border, the state's large Mexican-American population (as of 1990, over one-quarter of all Texans and approximately one-third of all children in its public schools) and the system of adoption hearings open to public participation. Yet in 1985, no vocal nor visible lobby had been on hand to argue for a coherent and informed treatment of Mexico and its peoples. In fact, during the three days of public adoption hearings held in Austin in July 1985, the words "Mexico," Mexicans" and "Mexican Americans" never once were uttered. Even in Texas in the late 1980s, there was ample evidence of the chronic and persistent stereotyping of Latin America and its inhabitants that specialists have long decried. ${ }^{7}$

Yet a notable leap in overall quality characterizes the textbooks submitted for adoption in 1991. While it is clear that market forces and other factors exert strong influences upon the precollegiate publishing industry, it is hard to discount the notion that the Columbus quincentenary has played a significant role in raising the consciousness of authors, consultants, editors, and publishers. For example, it hardly seems a coincidence that Macmillan/McGraw-Hill selected Gary Nash, a prominent social and cultural historian who has devoted decades to writing about non-Whites and non-elites in early American history, to author its volume for the 1991 adoptions competition. ${ }^{8}$ Regardless of what titles the individual school districts choose from the newly adopted list, Texas students should soon end up with U.S. history textbooks that finally begin to capture the excitement and nuances of the American past in sophisticated and sensitive ways. In general, the latest textbooks are fresh and intellectually stimulating; they are not the same tired rewrites of those nonanalytical narratives that have dominated the adoptions lists for decades. ${ }^{9}$ Moreover, the authors and publishers have made real ef-

6. See Salvucci, "Mexico, Mexicans, and Mexican Americans," for an extended analysis of the Mexico-related content of the 1986-1992 textbooks.

7. "Transcript of Proceedings before the Commissioner of Education and the State Textbook Committee," Austin, July 15-17, 1985; John L. Robinson and Ronald J. Morgan, "Myth Reinforcement: Latin America in Public Schools Textbooks," National Social Science Journal, (1988-89 Southwest Edition), vol. 2, no. 1, 52-63.

8. See Reinhold, "Class Struggle," for a discussion of how Oakland and some other heavily minority school districts in California have rejected the Nash text as "insufficiently multicultural." Yet, in his testimony before the State Board of Education on November 7, 1991 in Austin, Julio Noboa Polanco judged the Nash textbook to be the one most sensitive to multicultural concerns of the six under consideration for adoption in Texas: Author's notes from the SBOE hearing, Austin, November 7, 1991.

9. Members of the State Textbook Social Studies Committee (mostly veteran classroom teachers appointed by members of the board from their own districts) made this same point repeatedly when called before the microphones to testify at the hearing on November 7 , 1991. The elected board members remained incredulous at their endorsements of the 
forts to treat Mexico-related issues in an attentive and expansive manner. By utilizing writers and consultants well-versed in Mexican and Mexican-American history, publishers gained access to the latest-often pathbreaking-scholarship in these fields. There is very little of the "mindless mentioning" of minorities that permeated the 1986-1992 textbooks. Instead, Mexican perspectives and Mexican-American experiences are often woven into the larger story, thus adding a more complete dimension to United States history. The detailed assessment that follows alludes to some remaining problems, but should not diminish the real accomplishments of these new books.

Each of the textbooks adopted for use in Texas between 1992 and 1998 devotes considerable attention to Precolumbian civilizations and the Conquest. In fact, coverage is generally the most extensive and most sophisticated for these eras of the distant past, as it was in the 1986-1992 books. Topics such as the Columbian exchange are presented extremely well, allowing readers to appreciate the richness, drama, and consequences of Mexican history. Granted, there might be more explicit efforts to connect the rather folkloric material of the early chapters to precise, but more universal themes-such as imperialism and enslavement-that are subsequently raised. And some descriptive material—such as the large number of foreign proper nouns-might actually be reduced to avoid overwhelming student readers. Nevertheless, the message presented is one in tune with quincentenary-inspired cultural awareness: Mesoamerican peoples created advanced, influential, and complex civilizations that long predated the arrival of Europeans. Not one of the new textbooks resorts to examples of ethnocentrism reflected in at least two books on the 19861992 list. $^{10}$

The treatment of Mexican and Mexican-American history in the late colonial and early national periods is scant in comparison to its treatment in the pre-Conquest and Conquest chapters. However, the new textbooks offer accounts that devote somewhat more attention to early U.S.-Spanish boundary disputes and to the Mexican War for Independence than do the books used in Texas down to the spring of 1992 . Yet, even the more extensive discussions miss an excellent opportunity to explain the different political legacies of British and Spanish America. For example, Garraty's The Story of America notes that "the struggle to organize a government took three years. Finally Mexico's republic was organized and a constitution proclaimed in 1824" (p. 407). Likewise, Davidson and Underwood's American Journey: The Quest for Liberty ends a section by observing that "A few years later, Mexican leaders wrote a constitution that

"error-ridden" textbooks, and brusquely discounted the teachers' judgments in favor of the Gablers' testimony. Author's notes from the SBOE hearing, Austin, November 7, 1991.

10. Salvucci, p. 206: "The immense land masses as well as the tiny islands that the Spanish explorers had found were like gift boxes still unwrapped." Also, "Europeans first put them [Native Americans] in touch with the world." 
made Mexico a republic" (p. 387). In fairness, on the following page the authors do point out that the new Latin-American republics had a hard time setting up stable governments, since they had little experience in self-government, and that there were deep social divisions and economic problems. Still, both of these texts could have taken advantage of the opportunity to elaborate further, by explaining the distinctions between British and Continental conceptions of "republics" and "constitutions" and how each of these meshed with different political and socio-economic realities. In this way, the Mexican perspective would not have been merely alluded to in an off-handed and undeveloped manner, but would have been used to underscore the divergent colonial heritages as well as the uniqueness of U.S. political development. At the very least, students might learn a valuable lesson about false cognates, about how two cultures may have different working definitions of the very same words. Providing such careful background also helps to avoid the implicit ethnocentrism that so often accompanies related discussions of the Monroe Doctrine: "To guarantee the freedom of the new nations, President Monroe issued a statement warning Europeans not to interfere in the affairs of the Western Hemisphere" (Davidson and Underwood, American Journey, p. 397). Most historians allow that the story is far more complicated and considerably less disinterested than that.

Admittedly, the most difficult period to write about in the new textbooks involves the Texas Revolution and the battle of the Alamo. In the 19861992 books, there was considerable stereotyping about "blood-thirsty" Mexicans and "heroic" Texans. Now, Divine et al.'s America: The People and the Dream avoids such problems by offering a hurried, almost pithy account of the rebellion. The narrative is generally nonjudgmental and is accompanied by a painting which depicts the battle of the Alamo more accurately than most. Garraty's The Story of America, in turn, concedes that "government leaders in Mexico City naturally disliked the Texans' attitude" (p. 409); that "to the Mexican government this was a civil war" (p. 410); and that "the Mexicans considered [the defenders of the Alamo] traitors" (p. 410). Such movement away from a one-sided perspective teaches students that there is more than one way to look at an issue, and that most historical events are open to more than one interpretation.

This type of broadmindedness does not characterize the relevant chapter in Davidson and Underwood's American Journey. While it does dedicate more space than other texts to the conflict in Texas, the narrative is more narrowly focused on the traditional heroic qualities of the Texas Revolution. For example, developments in that region are not really placed in the context of other revolts in the Spanish borderlands in 183637, specifically in California and New Mexico. Instead, American Journey stresses Stephen Austin's "wise leadership," and the "hard-working [Anglo] people who knew how to take care of themselves" (p. 434). Likewise, it emphasizes that " $[\mathrm{d}]$ espite the odds against them, the Texans refused to 
give up" (p. 436). It also reprints the legendary message of William Travis ("hardly more than a boy") and records the high drama of "the gleam of [Mexican] swords in the sunlight." And the old racial stereotypes persist: "A Texan could fire three or four shots in the time it took a Mexican to fire one"; and the "heroic effort" of the defenders "bravely held them [the Mexicans] off" (last five quotations from p. 437). After the "five Texas survivors, including Davy Crockett, were promptly executed at Santa Anna's order" (p. 437), the "slaughter at the Alamo angered Texans and set off cries for revenge. The fury of the Texans grew even stronger three weeks later, when Mexicans murdered several hundred Texan soldiers at Goliad," but then at San Jacinto, the Texans triumphed, "although they were outnumbered" (p. 438). Is this still not the Alamo as John Wayne would have it? Of course, none of these individual assertions is unreasonable and all are more or less grounded in fact. But, taken together, they offer at best a one-dimensional understanding of the war. This picture simply is not complete: readers either remain oblivious to the other side of the struggle or are left to wonder what ever possessed the Mexicans to behave as they did. This single-minded perspective is reinforced by the section questions that follow: "Why did Americans in Texas come into conflict with the Mexican government?" and "How was the defeat at the Alamo also a victory for the Texans?" (p. 438). By contrast, the section questions from other texts are considerably less loaded. Divine et al.'s, America: The People and the Dream asks: "Why did American settlers and the Mexican government have problems with each other?" (p. 405); and Mason et al.'s History of the United States: Beginnings to 1877 queries: "What tensions existed between the Mexican government and AngloAmericans in Texas?" (p. 439).

This last textbook, Mason et al. 's The History of the United States, stands out for its distinctive organization. While the other three on the preReconstruction list divide up their coverage of the Mexican War for Independence, early Anglo settlement in Texas, the Texas Revolution, and the battle of the Alamo into separate chapters with different, apparently larger concerns, The History of the United States devotes all of Chapter 17 to "Changes in Spanish-Speaking North America, 1810-1836." The three sections deal with "Mexican Independence," "Changes on the Borderlands," and "The Texas Revolution" respectively, but they weave these topics together in an integrated, sustained, and comprehensive way. The historical explanation is intelligent, sophisticated, and sure to satisfy the curiosity of interested readers. To wit, the recounting of Travis's infamous line drawn in the dirt begins with "Many legends of the Alamo have developed over the years. One story about the siege says..." and ends with "Whether that story is true or not . .." (pp. 441-43). This confronts the important historical question of myth-making head on, and conveys the valuable lesson that historians sometimes disagree over exactly what happened. And while Santa Anna clearly emerges as the villain of this episode, 
teachers are nonetheless instructed to ask: "What consequences might [Mexican] soldiers have faced if they refused to follow orders and execute the prisoners?" (p. 443). Finally, this chapter takes the opportunity to set the stage for subsequent developments in the region's history: "After independence, the culture of Texas became increasingly intolerant of the region's Mexican heritage. Anglo-American immigrants ignored the contributions Tejanos had made to independence. The brutal excesses of Santa Anna and the fight against Mexico nurtured a spirit of revenge toward all ethnic Mexicans" (p. 444).

The desirability of such a revisionist approach is obvious to professional historians and educators, but most of the board members and witnesses at the 1991 public hearings neither appreciated the overall accomplishments of the new textbooks nor manifested much understanding of the discipline of history. Instead, the testimony presented was mostly thoughtless nitpicking or one-issue lobbying. For example, some accused the publishers of using incorrect maps that underestimated the true boundaries (and, therefore, the extent!) of the Republic of Texas. The spokesperson from the Texas Society of the Daughters of the American Revolution even suggested that the publishing companies had been "bribed by Mexico" or were guilty of a "conspiracy of ignorance." This same individual urged the audience to study the Treaty of Velasco to set the record straight. Yet the very text of the treaty which she herself provided noted that the Mexican Senate had failed to ratify it, thus making it a rather dubious basis for her assertions. ${ }^{11}$ In response to this type of unreflective commentary, the publishers' representatives gamely stood by their versions, citing, in turn, their own solitary sources. This pattern of exchange was repeated throughout the hearings, with the Encyclopedia Britannica emerging as a sort of historical bible. Indeed, the more frequently that witnesses resorted to this particular compendium of facts, the more their credibility appeared to grow. None of the members of the State Board of Education ever raised questions relating to how historians discriminate between opposing or contradictory facts, or to how we arrange our collected facts to tell particular stories. Instead, historical truth seemed easily and eminently attainable and, certainly, one-dimensional. In the minds of the participants at the hearings, as long as all of the "facts" were "correct," the process of doing history was complete. The role of analysis and interpretation in recreating the past was simply never addressed in any public assessments of the new textbooks.

The lack of informed and thoughtful discussion extended to another sensitive topic in bilateral relations, the Mexican War, known to Mexicans

11. "Written Comments concerning Textbooks reviewed by the State Textbook Social Studies Committee, 1991 Adoption" (Austin, Texas Education Agency, 1991), pp. 47 and 54; also, "Transcript of Proceedings, Joint Hearing before the Commissioner of Education and the State Textbook Social Studies Committee, July 9, 1991" (Austin, Texas Education Agency, 1991), pp. 16-17. 
as the "War of 1847" or the "American invasion." The older textbooks used to provide rather jingoist accounts of the fighting, placing it approvingly in the context of Manifest Destiny. But by 1986, a few authors pointed out that there was substantial disagreement about the war in U.S. political circles. The newly approved books demonstrate much more awareness of the magnitude of this war, not only as a formative experience for Americans, but also as an event that has deeply affected the Mexican psyche, influencing the relationship between the two countries even to this day. For example, Garraty's The Story of America indicates that the U.S. army marched inland to Mexico City, "following the route of Cortés" (p. 420). And Davidson and Underwood's American Journey pointedly notes that "Like the Texans who died at the Alamo, the Mexicans at Chapultepec fought to the last man. Today, Mexicans honor these young men as heroes" (p. 445). Readers of these accounts thus can appreciate that there are at least two sides to a conflict, and begin to correct the myopia that so often affects American views of international affairs. Yet, once again, the issue of historical perspective was never part of the public debate during the adoption hearings. One witness, for instance, objected to the following passage from Davidson and Underwood's, American Journey: "When Mexican Americans went to court to defend their property, they found that American judges rarely upheld their claims" (p. 447). She argued, in turn, that "over $\$ 3.4$ million was also spent to pay those citizens for their property. This should be stated to balance the caustic remark about our judicial system." 12

Along similar lines, the same speaker challenged an assessment drawn from Garraty's The Story of America: "Mexicans adopted the best of these [customs] and many other things despite the fact that Americans treated them like second-class citizens" (p. 424). In rebuttal, she listed a number of Texas counties "from $A$ to $Z$ " that were named for "Mexicans who were in Texas who were for the Mexican Revolution," "for the Mexican language," and "for those Mexicans who were in Texas." 13 When a subsequent witness, speaking in favor of more sensitive and informed inclusion of Mexican-American perspectives, suggested that "rattling off many different names of counties and cities with Spanish names... does not erase the historical fact that Mexican Americans were treated as secondclass citizens," he elicited an indignant outburst from veteran protester Norma Gabler, who asked: "Is he supposed to be talking about all that?" In a strictly procedural sense, of course, Gabler was correct; participants are supposed to confine their remarks to material found in the textbooks themselves and not engage in any kind of debate with each other. ${ }^{14}$ Still,

12. "Written Comments concerning Textbooks," p. 56.

13. "Transcript of Proceedings . . . , July 9, 1991," pp. 20-21.

14. "Transcript of Proceedings . . . July 9, 1991," pp. 32-33. The exchange continued until the hearings officer reprimanded Gabler for speaking out from the audience and instructed the witness, Julio Noboa Polanco, to confine his remarks to the specific books he 
their exchange does cause one to wonder about the extent to which the Columbus quincentenary has enhanced multicultural awareness among the public at large, at least in the Lone Star State.

Again, it is quite apparent that textbook authors, editors, consultants, and publishers have responded positively to initiatives inspired by the quincentenary, as well as to the larger national debate over educating U.S. students. And this, of course, is no small achievement, considering the previous deficiencies in textbook treatments of Mexico, Mexicans, and Mexican Americans. But the rest of the story is not so rosy. The process of textbook adoptions in Texas itself, the effectiveness of experienced witnesses at the hearings in manipulating the State Board of Education and the media, the media's superficial, if not sensationalistic, coverage of the flap over the errors, the myopic understanding of the nature of history education on the part of several members of the board, and the continued indifference of the public at large, particularly those parents with schoolage children, all contribute to a situation still in need of improvement.

The adoptions process allowed publishers only twelve months from the issuance of "Proclamation 67" (or the specification of "essential elements" and content-related requirements) to deliver sample texts to the State Board of Education (in this case, from March 1990 to March 1991). These versions were then deposited for barely two months (April to June 1991) at regional service centers across the state for public perusal. Interested Texas citizens had the right to submit unlimited written comments at the end of that period to the State Textbook Social Studies Committee, or to sign up to appear at a public hearing (in July 1991), where testimony was limited to ten minutes per speaker per adoption category. The publishers scrambled to respond to these written and oral criticisms over the summer, so as to submit their finished products at the board's meeting in the fall, where interested citizens who signed up in advance could speak for three minutes. Meanwhile, the State Textbook Social Studies Committee, composed mostly of current classroom teachers and educational administrators, voted (in July 1991) on which books to recommend to the board for adoption. Board members then were scheduled to take a final vote at the fall meeting (which was postponed in this instance until January 1992 for most of the books, although the last adoptions contract was not issued until March 1992). School districts across the state subsequently had two months (April and May 1992) to decide which of the adopted books to order. The new textbooks are scheduled to be in use in Texas classrooms by the coming school year (August 1992). In this case, such a compressed

\footnotetext{
had signed up to discuss. Earlier during this same hearing ("Transcripts," p. 9), Gabler's spouse had complained about favorable treatment of Pre-Columbian peoples in the textbooks: "Regarding the Mayas, the Aztecs, and the Incas, there's a lot of positive information portraying them as being creative, industrious, a lot of positive comment, but very, very little about the fact that all three of these cultures were brutal, violent, evil, offered human sacrifices and so forth. I think there should be a balance."
} 
timetable obviously compounded the publishers' problems with quality control; moreover, it did not allow sufficient opportunity for thoughtful examination by the public at large or even teachers and school board members at the district level. Indeed, despite all of the elaborate rules to encourage fair competition and open access that are written into the system, most of the handful of "concerned citizens" who testify have considerable experience with the process and are well-known (if not wellregarded) in state political and bureaucratic circles. ${ }^{15}$

The Gablers released their initial list of errors to a few of the board members immediately prior to the November 7 meeting. Reporters on hand rushed to interview the couple and their most vocally outraged allies on the board, who accepted the "factual errors" at face value. Early media accounts never raised the issue of any possible political motivation behind the dramatic and carefully orchestrated announcement. Likewise, the entire Board of Education later sat in silence as other groups besides Mexicans and Mexican Americans-including Blacks, homosexuals, feminists, and liberals - came under attack from many of the veteran textbook protesters. Nor did the print and broadcast media bother at first to analyze critically the material so willingly put out by the Gablers. Instead, the former told the story incompletely and from merely one point of view. Only The Wall Street Journal-and, then, some three months after the hearingsreported Mel Gabler's own candid admission that, by emphasizing the factual errors, he hoped to "draw attention to his criticisms of the books on moral and political grounds." In this context, it hardly seems a coincidence that the textbook deemed by him as the most inaccurate is the one praised by others as the most sensitive to multicultural concerns. ${ }^{16}$

Media coverage also emphasized the most egregious of the errors, and at the outset ignored the fact that at least 90 percent of them turned out to be typographical rather than substantive in nature. The now-defunct $D a l$ las Times Herald relied upon one board member's eager distribution of the Gablers' findings and even ended up printing a statement that was, if not incorrect, at least misleading and incomplete. "Book: 'Lincoln issued the Emancipation Proclamation on Sept. 22, 1862.' Fact: 'The proclamation to free slaves was issued Jan. 1, 1863.' "17 Actually, Lincoln did issue the proclamation on Sept. 22, 1862, with the stipulation that it would take effect on Jan. 1, 1863. And the historical significance of this act-

15. "The great textbook fiasco," San Antonio Express-News, May 3, 1992, offers a succinct and useful summary of the recent adoptions process. The author also consulted volumes of official documentation from the Texas Education Agency, beginning with "Proclamation 67," which contains the all-important content guidelines for publishers intending to compete in the 1991 adoptions.

16. Putka, The Wall Street Journal, February 12, 1992. Also, refer back to note 8 above, as well as the evaluation of Julio Noboa Polanco in "Additional Written Comments concerning Textbooks reviewed by the State Textbook Social Studies Committee, 1991 Adoption" (Austin, Texas Education Agency, October 1991), p. 211.

17. "Errors delay approval of school texts," Dallas Times Herald, November 8, 1991; see sidebar accompanying article on p. Al7. 
according to many professional historians-is that it freed slaves only in those territories in direct rebellion against the United States (i.e., in the Confederacy) and only in those parts of the Confederacy not under occupation by Union troops. Yet, such unnuanced reporting unfortunately left the public at large with many false but lingering impressions about the quality of the textbooks. ${ }^{18}$ And history itself ended up being politicized by the very people who claimed to champion factual accuracy and objective truth.

So where do we go from here? Getting the facts straight is only the first, albeit necessary, step in teaching and learning history. Historians and educators need to get this message out to students and, it seems, to elected officials, which means greater involvement by professionals in public processes like the Texas adoptions hearings. For those concerned with Mexico-related issues, it means less reiteration of the long-standing criticisms of textbook images and more active effort to articulate some fundamental principles for improving the education of American students. Recently, the Task Force on Mexico in the K-12 Curriculum has produced a pamphlet entitled "Key Understandings and Instructional Guidelines for Teaching and Learning about Mexico."19 Projects like these are the logical next step, a vivid demonstration to the sometimes indifferent public that the facts just don't speak for themselves.

18. Julio Noboa Polanco continued his involvement in the selections process, by testifying before the Northside (San Antonio) Independent School District Board on May 11, 1992. Over half the student population in this district is Hispanic, yet the board did not consider multicultural issues at all in deciding which one of the adopted textbooks to order for its schools. Noboa Polanco thinks that negative publicity for the Nash text (which was his clear preference but had been characterized back in the fall at the board meeting as the most error-ridden) eliminated it from serious consideration at the local level in this case.

19. The Appendix reprints the Key Understandings for Teaching and Learning about Mexico from this pamphlet. The complete pamphlet, "Key Understandings and Instructional Guidelines for Teaching and Learning about Mexico," is available from Elsie Begler, ISTEP, Center for Latin American Studies, San Diego State University, San Diego, CA 92182 . 


\section{Appendix}

Key Understandings for Teaching and Learning About Mexico

I. Mexico's role in the world today is significant in its own right.

II. Mexico is a country of extraordinary regional diversity.

III. Mexico is a country undergoing significant social, economic, and political changes.

IV. Mexican culture is a unique blend of thousands of years of human interaction.

V. Mexican perspectives are rooted in a past which represents "another American experience," significantly different from that of much of the United States.

VI. Mexico's influence on U.S. history and society has been, and will continue to be, significant.

VII. Mexico and the United States are partners in an increasingly important bilateral relationship.

These key understandings are taken from "Key Understandings and Instructional Guidelines for Teaching and Learning about Mexico," a pamphlet produced by the Task Force on Mexico in the K-12 Curriculum. The complete pamphlet is available from Elsie Begler, ISTEP, Center for Latin American Studies, San Diego State University, San Diego, CA 92182. 